\title{
Devolution of Power to Local Government: Appraising Local Government Autonomy under Nigerian Federation
}

\author{
Emmanuel Ibiam Amah \\ Faculty of Law, Ebonyi State University, Abakaliki, Nigeria \\ Email: amahibiam@gmail.com
}

How to cite this paper: Amah, E. I. (2018). Devolution of Power to Local Government: Appraising Local Government Autonomy under Nigerian Federation. Beijing Law Review, 9, 275-293.

https://doi.org/10.4236/blr.2018.92018

Received: April 3, 2018

Accepted: June 18, 2018

Published: June 21, 2018

Copyright $\odot 2018$ by author and Scientific Research Publishing Inc. This work is licensed under the Creative Commons Attribution International License (CC BY 4.0).

http://creativecommons.org/licenses/by/4.0/

\begin{abstract}
There are typically three levels of government: the national, the states or sub-national and the local governments under the Nigerian federation. Over the years the ideal position and status of the local government as a third tier government have been of constant debates. These debates hinge primarily on the autonomy status of the local government. This article critically examines this pertinent issue of local government autonomy under a federal structure. The critical issues of the relations between the federal government at the centre and the local governments at the grassroots and between the sub-national governments and its local Governments are the central subjects of this work. The doctrinaire research methodology was adopted herein as the work examining the Nigerian Constitution and other legal framework pertaining to local governments in Nigeria. This work finds that the Nigerian constitutional provisions pertaining to local governments laid the basis for the unhealthy interference of both the federal and states' governments over local government's administration. Constitutional amendment aimed at freeing the local government system from federal control and interference and allowing it to be under the control and management of their respective states' government is herein advocated. In conclusion, federal system of government accommodates local governance under the control and management of the sub-national government. The idea of further devolution of full political autonomy to a local government within a sub-national territory is a myth and a mirage.
\end{abstract}

\section{Keywords}

Federation, Devolution of Power, Autonomy, Local Government, Grass Root Development 


\section{Introduction}

In most federal states, two or more levels of government are created one at the national level and others at the regional or sub-national level described variously as states, provinces, cantons and so on and at sub-sub-national or local units called the local councils, municipal councils, county, districts, province, city, township, borough, parish, shire, village etc. in such a manner that governmental powers and functions are allocated to these levels of government. This is a form of devolution of power.

A federal system of government organization encourages devolution of powers among a central national government and other regional or decentralized government in such a manner that governmental powers and functions are shared among these two or more levels of government, according to each level of government independent and autonomy in their respective spheres by means of a constitutional allocation.

Devolution under a federal arrangement seeks to transfer political, administrative and economic authority from the centre to the local communities and further seeks to promote popular participation in decision making, enhances accountability and responsible representation and aims to introduce efficiency and effectiveness in the generation and management of resources for the over-all development.

The paradigm shift toward devolutionary federation is basically a reflection of the ideological lean toward responsible and accountable government system which in the electorate is entitled to determine their political destiny. ${ }^{1}$ This is premised on the assumption that humans if entrusted with its own destiny through the medium of local democratic institutions can govern themselves in relative peace and dignity in their pursuit of collective goals. Devolution of power is a form of decentralization of power aimed at promoting rapid development of a country through the establishment of local government. Devolution helps prevent too much concentration of political and economic power at one level which inevitably leads to "managerial constipation". ${ }^{2}$ Devolution of power to local people encourages active political participation which acts as a restrain against tyranny and dictatorship which may occasion as a result of the central government being remote from the local people.

Devolution of power to local people at the grass root enhances the legitimacy of government and its programmes. Economically it enables government to distribute local public goods and services according to the local needs. It further encourages healthy competition between the various sub-national and local gov-

${ }^{1}$ Omale, I., New Perspectives in Public Sector Management in Nigeria, (Ankpa: Ultimate publishers, 2005) p. 5.

${ }^{2}$ S. Dalhatu, Essays on Local Government Administration: Fostering Better Service Delivery, Record Keeping, Accountability and Empowerment at the Local Government (Kano: Benchmark Publishers, 2006) Cited in K. Asaju, "Local Government Autonomy In Nigeria: Politics and Challenges of the 1999 Constitution”; International Journal Of Advanced Legal Studies and Governance vol. I No 1, April 2010 p. 99. 
ernments which results in innovative social and regulatory policies and politically it secures greater participation and opportunities to local minorities in government and her decisions making process thereby preserving their distinctive autonomy and linguistic identities. According to Ortega Y.G; Devolution of power not only assuages the need of cultural and language identities of subgroups but electrifies citizens' interest in matters of governance. ${ }^{3}$ Devolution of power to local communities is therefore a critical element of good governance and a hallmark of a viable federation as it is imbued with additional checks and balances on the central government and a degree of security for constitutional order and social stability that are vital for economic order and development. ${ }^{4}$

Devolution of power to both sub-national and local governments however has its own challenges. One is the institutionalization of the balance of power between and amongst the national government and the sub-national and the local government powers and resources. Second is the critical issue of the relations between the central government and the sub-national governments as well as the local governments and between the sub-national government and its local Governments, so as to encourage healthy cohesion and interaction. Put in other words, should the local government be depended on the Federal (central) or the states (sub-national) government or to both? Or should it exist as a purely independent tier of government with autonomy over its affairs, as it is with the federal and states government under a federal arrangement? The onerous task on constitution and policy makers is to ensure that the above issues and other related matters are dealt with in an efficient and effective manner to minimize friction and unhealthy competition and encourage cooperation for efficient and effective governance and development.

Under the Nigerian Federal arrangement while the constitution demarcated and allocated legislative functions between the national/federal government and the states, the local governments were made to function based on laws made by the states (the sub-national) legislatures. This deliberate state of affair has generated much controversy among Nigerian constitutional and political commentators as most proponent of local government autonomy have favored the total devolution of autonomous power and functions on the local government councils, while others favour the status quo whereby the local government remains the appendage of the states government. In the very recent past this matter reached a crescendo as the National Assembly debated over the issue of granting more autonomy to the local government councils.

In this paper, we examined the status of the local government under the Nigerian federal constitution, relationship that should exist amongst the federal government at the centre, a sub-national government and that of the local governments at the grassroots, and the central question of autonomy of local govern-

${ }^{3}$ See J. Rodden and S. Rose-Ackerman; Federation Preserves Market (1997) 83 va. LR 1573 at P. 158 cited in John Hatchard, Muna Ndulo, Peter Slinn, "Comparative Constitutionalism and Good Governance in the Commonwealth" (UK, Cambridge University Press, 2004) p. 185.

${ }^{4}$ See Preamble European Charter of Local Government Council of Europe Treaties E.T.S No 122. 
ment council within a federal arrangement as well as the extent and limit to such autonomy. Before then we shall briefly examine the issue of the search for local government autonomy in Nigeria from a historical perspective. This is with a view to appreciating the intricate nature of the vexed issue of local government autonomy in Nigeria.

\section{Local Government Development in Nigeria, Historical Perspective}

Local government simply means government at the local level or Local government at the lowest tier of administration within a country. It is a political sub-division of a nation state which is constituted by law and possesses substantial control of local affairs including the power to impose taxes or to exact labor for specified purposes. ${ }^{5}$ Such a body being elected under a democratic process; ${ }^{6}$ according to the 1979 local government reform handbook, ${ }^{7}$ local government is a government at the local level exercised through representative councils established by law to exercise specific powers within defined area. ${ }^{8}$ In practice however, a local government administrator may not be necessarily elected. Thus it could be defined as 'the form of government operated in a restricted geographical area within a nation or state, through local election or selection and it enjoys independent autonomy including the power to impose taxes. ${ }^{9}$ It is a system of local administration under which local communities and towns are organized to maintain law and order, provide some limited range of social services, and public operation and participation of the inhabitants in joint endeavor towards the improvement of their living. ${ }^{10}$ The primary duty of local government includes local economic delivery, provision of public services at the local level and environmental protection and preservation. Local governance touches the people's daily living in the area of education, welfare, market, amusements and recreation, culture, hobbies etc. Thus local government ought to handle services like public parks and recreation services, local police, housing, emergency services like healthcare, and fire services, transportation services, sewage disposal and refuge dumpsites, streets work, sewers, signage and so on.

A local government must therefore be a legal entity distinct from the states' and federal governments and ideally administered by democratically elected officials with specific powers and functions and with a degree of autonomy to car-

${ }^{5}$ Federal Republic of Nigeria, Guidelines for Local Government Reforms. (Kaduna: Government Printers, 1979) p.77.

${ }^{6}$ See UN Office for Public Administration, cited in Asaju K. op. cit. See also Appadorai, A., The Substance of Politics, (New Delhi, Oxford University Press, 1975) p. 288.

${ }^{7}$ Guidelines for Local Government Reforms, op.cit.

${ }^{8}$ Cited in, Agboola T.O., the Challenges of State/Local Government Creation in Nigeria Critical Analysis, International Journal of Politics and Good Governance, Vol. VII No. 7.1 Quarter 1, 2016, p.4.

${ }^{9}$ C. P. Ekukpo; local government administration in modern Nigeria (Ikot Ekpene, Egme Publication, 1994) p. 1

${ }^{10}$ G. A. Odenigwe, A New System of local government (Enugu, Nwamife Publishers, 1977) p. 19. 
ry out its functions, and resources to manage them. In a federation, local government fell into the third or even in some cases the fourth tier of government. In Nigeria it is the level of government other than the other two well known levels or tiers; the federal and state governments. A Local Government Area stand for the defined geographical locality over which a local government or council exercises authority. A Local Government Council means a body of persons who administer the governmental affairs of the local area as provided in the Constitution. $^{11}$

The history of local government in Nigeria predates its federalism. Colonial system of local government administration was based on the British unitary model of administration where in the local governments were managed and controlled by the central government. The British government through the indirect rule system of administration depended on the traditional political institutions for the running of local administration. The colonial administration of local government through the indirect rule system required that administration at the local level be carried out through the existing traditional rulers and institutions. In the areas where there were no existing traditional rulers or institution like in the south eastern part of Nigeria, new ones were created in the form of warrant chiefs. It need be recalled that prior to colonialism, local government administration were as diverse as the multi ethnic configuration of the Nigerian polity. Thus the indirect rule system employed by the British colonial government sought to establish a system of local administration through the existing traditional institution and authorities. ${ }^{12}$ The use of indigenous political institutions for the purpose of local government was contingent upon modification of some aspects of traditional government repugnant to European ideas.

The Native Authority Ordinance promulgated in 1910 which gave impetus to the indirect rule system recognized the traditional ruler as sole authority reposed with the functions of maintaining law and order. The indirect rule system of native administration however was only successful in the northern part of the country, especially the Muslim dominated areas due to the existing operational and centralized traditional institutions which recognized the monarch (Emir) as the absolute sole authority. Thus in the emirate system of the northern Nigeria, the Emirs stood at the top of the native administration, local government was under the supervision of district heads appointed by the Emir. Each district was divided into villages headed by the village heads. The district and village heads were charged with the duty of maintaining law and order, collection of taxes and settling minor disputes. These taxes were to be transmitted to the Emir at the top. The indirect rule system achieved some measure of success in this centralized and powerful traditional institution of northern region of Nigeria.

In the southern part of Nigeria however, the system was greeted with resistance. In the south-west where there were existing traditional institutions, tradi-

\footnotetext{
${ }^{11}$ Section 7(5) 1999 CFRN.

${ }^{12}$ Agboola T.O., the Challenges of State/Local Government Creation in Nigeria Critical Analysis, International Journal of Politics and Good Governance, Vol. VII No. 7.1 Quarter 1, 2016.
} 
tional rulers were not recognized as absolute rulers. The Oba's playing the role of constitutional monarchs ruled their kingdom with the council of chiefs. The Calabar areas of the south-south part of Nigeria had the system of council of chiefs headed by the Obong, Ndidem or Etuk as the case may be. Decision was reached by the councils. Thus the indirect rule system fared poorly in these parts of Nigeria. In the south east of the predominantly Igbo tribes, there were no existing traditional institutions as the traditional system were more of republican consensus. The decision making were based on the family heads, the lineage, the village and the town chiefs (title holders) who enforces the decisions made by the general assembly of all males (or of all family heads). To address this lacuna in the south eastern Nigeria and in a bid to maintain a uniform system of administration throughout the country; the colonial government created an artificial base known as warrant chief. This system was quite alien to the people of south eastern Nigeria and was therefore adversely welcomed. The eastern part of Nigeria as has mentioned earlier lacked the existence of a large scale hierarchical organized state or centralized authoritarian political system. Thus the system of indirect rule did not just fared badly but crumbled in this part of Nigeria. ${ }^{13}$ In other parts of the country, most especially the northern region, despite some problems such as unqualified staff, insufficient native resources and lack of definite long range policy in the democratization of native authority, the colonial system of local government authority provided a form of stable local administration which strengthened the base of the colonial government in the maintenance of law and order.

The adoption of a federal system of government in 1950 marked another stage of local government development in Nigeria. The composition of the country into three regions impacted on the local government system. Local government therefore came under complete control and supervision of the regional governments under a federal Nigeria. ${ }^{14}$ Each region adopted its own type or form of local government system ${ }^{15}$ and this remains the prevailing situation up till 1966 before the military incursion into the Nigerian politics. Local government existed as bodies created by the regional government purely to deal with such matters of local concern as markets, minor roads, recreation grounds, libraries, health, sanitation; housing and so on under the direct supervision of the regional and later states ministry of local government affairs. ${ }^{16}$ The local authorities were

${ }^{13}$ P.A.O, Oluyede, Constitutional Law in Nigeria (Ibadan, Evans Brothers Nigeria Publishers Ltd., 1992) p. 302.

${ }^{14}$ In the eastern region was the Eastern Region Local Government Ordinance of 1950, in the West, the Western Region Local Government Law of 1952 and in the North the Native Authority Law of 1954.

${ }^{15}$ In south eastern Nigeria the Warrant Chief System was replaced by the Clan Council System or "Chiefs in Council" which introduced some element of representative democracy into local government in 1953. P. A. O. Oluyede, op. cit.

${ }^{16}$ A. O. OJO; Political Science and Government of Nigeria (Ilesha; Ilesanmi Press Limited, 1773) First Edition p. 254, B. C. Nwankwo; Authority in Government, Nigeria and World Politics in Focus (Enugu, Almond Publishers, 1992) p. 155. 
required to act within the confine of the regional instruments creating them while their major sources of revenue were grants from the regional government. Further key officers of the local administration were appointed by the regional government and their budgets were subject to the approval of the regional legislature. Further the regional government had powers to audit the account of the Local Government councils and may reduce or withhold her grants or approval of loans.

Following the advent of military government in Nigeria, a number of reforms were introduced into the local government system. ${ }^{17}$ One of the significant innovations was the establishment of the local government as a third tier government under Nigeria federation. Under this system local government became a federal affairs enjoying direct allocation of funds from the federation account. The federal military government created a number of new local government areas. These were as a result of the prevailing demands at these periods that the local government be separated from and be made independent of the state's government. ${ }^{18}$ These demands were occasioned by the incessant and irritating interference with local government administration by their state government and the rampant cases were elected local government councils were capriciously dissolved and replaced by appointed agents of the state government called care taker or sole administrators as well as the neglect and denial of funds for carrying out functions assigned to local government among others.

The military government at the centre in order to kick start the implementation of the total reforms in line with the above stated demands abolished the state ministries of local government affairs, established the executive and legislative arms of government in local communities and provided direct allocations of funds to local government without passing through the state government. Thus the scheme of devolution of power was geared toward transferring greater power and resources to the local governments rather than to the states. ${ }^{19}$ This reform was therefore made at the expense of the state thereby provoking negative reaction from the states and suspicion about federal motives in promoting these reforms. Thus during the period immediately following the making of the 1979 Constitution, most of these reforms were abandoned.

\section{The Status of Local Government under the 1999 Constitution of the Federal Republic of Nigeria}

The existence of the local government in Nigeria is specifically guaranteed by section 7(1) of the Nigerian Constitution. The territorial boundaries of the Local

${ }^{17}$ Gboyega, A. (2001). "Local Autonomy in Federal politics: The Nigerian Local Government System in Historical Perspective", Being a paper presented at an International Conference on New Directions Federalism in African, Abuja Nigeria.

${ }^{18}$ B.O. Nwabueze, Constitutional Democracy in Africa vol. 1 (Spectrum Books Ltd, Ibadan) 2003 p. 155.

${ }^{19}$ Orewa, G. O. and Adewumi, J. B. (1992). Local Government in Nigeria: The Changing Scene: Vol. II, Benin City: Ethiope Publishing Corporation see also Igbuzor, O. (2003). Local Government Reform and Constitutional Review in Nigeria. Lagos: Centre for Democracy and Development (CDD). 
Government Areas are further enumerated in the second column of part lof the First Schedule to the Constitution. ${ }^{20}$ Following the provision of section $7(1)^{21}$, the local government is a creation of the state government. ${ }^{22}$ Thus while it is mandatory for the state to ensure the existence of local government, local government cannot be said to have the status of a third tier government with autonomous status.

Although section 162(3) of the Constitution ${ }^{23}$ made provision for funding of local government by both the federal and state governments, the said section also provided for a local government and state's joint account to be managed by the state and through which the state shall transfer funds to each of the local governments of the state. ${ }^{24}$ This provision placed the local government under the financial control of the state government. Further, section 2(2) and 14 of the Constitution made Nigeria a federation consisting of states and a federal capital territory. No mention was made of local governments. Section 4 of the Constitution also divided legislative powers between the national and the state's government only. No legislative powers were constitutionally granted to the local government. The Nigerian Supreme Court ${ }^{25}$ in affirming the dependency status of the local governments on the state government emphasized the fact that the federal government of Nigeria has no constitutional legislative powers with respect to the establishment, structure, composition, finance and functions of local government councils, rather it is the states' governments that are bestowed with such powers under the Constitution. The Court stated further that the purport of sections 3 and 7 of the Constitution was to enumerate the federating units and their geographical areas as well as to identify the federal capital territory and nothing more. ${ }^{26}$ Therefore, since local government is a function of the state government and only the state government has the constitutional power to establish local government and to define its structure and function, it clearly and necessarily follows that local government is neither an independent third tier government nor is it an autonomous entity in the sense of possessing its own free will in the determination of its affairs free from control of any government.

It may notwithstanding be rightly argued that the effect of the constitutional provision for the existence and creation of local government is to mandate or obliged the states government such that the states are deprived of any discretion to do otherwise. Thus the Constitution obliges a state government not only to make the necessary legislation to provide for the establishment, structure, composition, functions and finances of local government councils but very importantly to ensure the existence of democratically elected local government coun-

\footnotetext{
${ }^{20}$ Gboyega, 1999 CFRN.

${ }^{21}$ supra.

${ }^{22}$ Ugwu, S.C., Issues in Local Government and Urban Administration in Nigeria. Enugu: Academic Publishing, 2001, p. 19 (Company).

${ }^{23}$ supra.

${ }^{24}$ Subsections (6) and (8) of the section 162 supra, see Ugwu, S.C., op. cit. Nwabueze (1983).

${ }^{25}$ Chief Balogun v A.G Lagos State \& Ors (1981) 1 NCLR 31, cited in Oluyede, op. cit. pp. 318-319.

${ }^{26}$ Chief Balogun v A.G Lagos State \& Ors. supra.
} 
cils under such law. This position is supported by a number of judicial decisions where in the court declared void the suspension and subsequent dissolution by state governor of an elected government councils and the appointment of caretaker or management committees in their place as a violation of the constitutional guarantee of democratic elected local government councils. ${ }^{27}$ Also the states are further obliged to make provisions enabling the local government to carry out certain enumerated functions ${ }^{28}$. However the local government can only carry out its functions pursuant to a law made by the state house of assembly for this purpose, thereby placing the local governments under the direct control of the state government. ${ }^{29}$

\section{The Vexed Issue of Local Government Autonomy under Nigerian Federation}

The term local government autonomy connotes local self government or grass root democracy. It connotes local government management authority with the will of its own and freedom to develop policy direction and pursue its development plan free from dictation from outside source. Local government autonomy serves not only the historical cultural and linguistic aspiration of the local people but draws the local citizen closer to the centre of power by increasing his/her capacity to control and participate in the decisions of government. Local autonomy can deepen democracy by bringing government closer to the people. It increases the opportunities for political participation and thus helps foster the creation of a democratic culture in a country. Locally elected leaders know their constituents better than central authorities and so are well adapted to provide the public services needed at the grass root. When things go wrong, physical proximity also makes it easier for citizens to hold local officials accountable for their performance. Further local autonomy is best suited for sub-national government with further divisions and cleavages along geographic or ethnic lines. It provides for a fair playing ground for minority opposition groups and parties which might otherwise be excluded from political power to exercise an influence and to make their voice heard. Local self government therefore encourages inclusive governance.

Local government autonomy ensures that the delivery of most government services is devolved to the local level thus taking the burden off the already over extended central or sub-national government. ${ }^{30}$ Autonomy entails the existence of local communities endowed with democratically constituted decision-making bodies and possessing a wide degree of independence with regards to their responsibilities-the way and means by which those duties are carried out and the

\footnotetext{
${ }^{27}$ Adeniji Adele and ors v. Governor Lagos state and ors (1982) see other cases e.g. Akpan v. Umah (2002) FWLR (Pt 110)1820, Victor Akpan v. A.G. Cross Rivers State \& Ors (1982)2 FNR 177, Akinpelu v. A.G. Oyo State (1982)2 FNR 428.

${ }^{28}$ See section 7(1) CFRN.

${ }^{29}$ Asaju K. op. cit.p. 107.

${ }^{30}$ M. Stoddard; 'South Africa's Election: Establishing Democracy at the Grass Root; (1997)21, Fletcher. F world affairs 83 at p. 85 cited in John Hatchard et al. (eds.) op. cit.
} 
financial resources required for their fulfillment. The existence of local authorities with real governmental functions can provide for more flexible responses adapted to local needs thereby alleviated the responsibility of an over-stretched central government.

Legally speaking however, autonomy means more than as expressed above. Autonomy will require not only the legal and physical existence of an apparatus of government like a legislative body, executive organ etc. but that the government must exist not as an appendage of another government but as an autonomous entity in the sense of being able to exercise its own will in the conduct of its affairs free from direction of another government. ${ }^{31}$ Such an autonomous government would not be constitutionally bound to accept dictation or directive from another rather it will enjoy discretion in relation to its affairs. ${ }^{32}$ This presumes that local government must possess the power to take decision independent of external control within the limits laid down by the law. It must garner efficient resources, particularly of finance to meet their responsibilities. In other words, local autonomy is the freedom or independence in clearly defined issues, areas as well as separate legal identity from other levels of government. Discussion on local government autonomy in Nigeria is usually premised in the relative independence of local government free from control by either the state or the federal government or both. It is the nature and structure of these interactions among these three levels of government that reveals the degree of autonomy of the local government system.

The autonomy of local government lies on two primary criteria. The first being that the local government shall posses the freedom to make integrated regional development plan including economic, social and environmental plans and the second being that it shall freely be able to set its priority in its budget expenditure. The fact that central or provincial governments and in some cases both central and provincial governments make grants and subsidies to the local governments enable them to penetrate into these local governments thereby dictating their development plans and policy directions. ${ }^{33}$ Thus in reality, local government autonomy in the legal sense, is a mirage. In USA for example, Local government system is not part of the federal Constitution. Therefore unlike the federal and the states government, cities, towns and other municipal councils have no independent constitutional standing, instead the power to create local governments rest with the states. Each state decides what type of local government that will exist within its border and what powers they may exercise. ${ }^{34}$

\footnotetext{
${ }^{31}$ B.O. Nwabueze; Federalism in Nigeria under the Presidential Constitution (London, Sweet and Maxwell, 1983) p. Davey K.J. "Local Autonomy and Independent Revenue" Journal of Public Administration, O.A.U. 1995 p. 17.

${ }^{32}$ Nwabuze, Ideas And Facts in Constitution Making, The Morohundiya Lectures, 1993, p.244.

${ }^{33}$ See N. Sasaki (1984) Atarashii Chiho Seihu (the New Local Government) Ashi Shobo, cited in Kimura, Limit of Good Governance in Decentralization and Local Autonomy-Ideal and Reality of Local Governance.

${ }^{34}$ See Perverill Squire et al. Dynamics of Democracy $2^{\text {nd }}$ edition, (Chicago, Brown and Benchmark) 1997, p. 52.
} 
Therefore in practice, local governments administration manages and supervises the local police and fire services, academic institutions and libraries, car parks and recreational facilities, ambulance and emergency medical services, transportation, sanitations and so on. These functions are usually provided in the respective states' constitutions which are usually more details and wider in scope compare to the federal constitutions. Further, the governing bodies of these local governments are usually elected by the people. Also, under the Swiss federation, the federal constitution recognized municipal autonomy in accordance with the Cantonal Constitutions and laws. ${ }^{35}$ Thus the scope and extent of municipal autonomy is dependent on the contents of the respective Constitutions of each of the Cantons. In practice however, local government autonomy is well rooted in Switzerland. The local administrations possess substantial levels of autonomy in the area of finance as well as direct democracy. ${ }^{36}$ Political autonomy in Switzerland is so developed that citizens can acquire political rights within three months of their resident in a particular municipality. ${ }^{37}$ In fact most of the municipalities have legislative councils with powers to make legislations regulating local services such as streets, water, parks, schools, transportation, electricity, fire service and local police, etc. Although the Swiss Federal Constitution guarantees autonomy to the local governments of the federation, the federal government cannot interfere with the manner of the exercise of Cantonal' rights over their local governments except to the extent that Federal courts hearing appeals from the municipalities may enforce. ${ }^{38}$ This is possible because under the Swiss Federal Constitution, the federating units (the cantons) are pronounced sovereign to the extent allowed by it. ${ }^{39}$ The federal and state governments however can indirectly interfere with local governments through the grant-in-aid programmes whereby financial grants made to the local councils are tied to specific projects to be supervised by the federal or state agency as the case may be. These federal or state agencies can insist that the local governments' carries out their obligations as attached to the grants. ${ }^{40}$

The Search for Local Government Autonomy in Nigeria has indeed been long and endless. ${ }^{41}$ By the 1950's the outgoing colonial government introduced a

\footnotetext{
${ }^{35}$ Article 50 (1) of the Swiss Federal Constitution of 1999.

${ }^{36}$ Congress of Local and Regional Authorities,

"https://rm.coe.int/local-and-regional-democracy-in-switzerland/1680750d61">ReportCG33(2017)1 $4</$ a $>$ (Accessed 25/04/2018).

${ }^{37}$ See Article 39, paragraph 4 of the Swiss Federal Constitution of 1999.

${ }^{38}$ Congress of Local and Regional Authorities, op. cit.

${ }^{39} \mathrm{~V}$. Bhagwan and V. Bhushan, World Constitutions, A Comparative Study Ninth Revised \& Enlarged Edition(New Delhi, Sterling Publishers Limited, 2009) p. 311.

${ }^{40}$ S. Gamkhers, M Pickerill, "the State of American Federalism 2011-2012" a Fend for yourself and Activist Form of Bottom-up Federalism "in Publius: The Journal of Federalism, (USA Oxford University,2012) A.M. Rivlin (2012), Rethinking Federalism for more Effective Governance" in Publius, ibid., See Perverill Squire et al. Dynamics of Democracy $2^{\text {nd }}$ edition, (Chicago, brown and benchmark) 1997, p. 52.

${ }^{41}$ D.O. Adeyemo (2005) "Local Government in Nigeria; A Historical Perspective" p. 80, Journal ot Local Government Studies, O.A.U December 16, 2005.
} 
number of reforms aimed at democratizing local government. These reforms ended up bringing the local government system under the strong grip of the regional governments. The successive military administration after independence tried to reverse this trend but ended up creating local government that was under the direct control of the central government; a system that was adverse to federalism. Proponents of local government autonomy in Nigeria have consistently advocated for a system of local government with independent existence as a third tier of government. The independent demanded for the local government to make it a third tier government under the federation was to terminate the status of local government as an agency of the state's government and to establish it as a government existing separately from and independently of the state government. The division of government powers and revenue in the Constitution would thus be transformed from a dual to a tripartite basis involving the federal and state and local governments on the same principle of equality between them. Under this proposal, a local government is to relate to the state government in exactly the same way as the latter relates to the federal government. Not only will its existence and democratic feature be guaranteed in the constitution. It is also to have reserve to it a sphere of functions from which the state government would be excluded. In other sense, the functions of the local government are not to be concurrent to the local and state government they are to belong to the former at the exclusion of the state government.

The effect of a tripartite division of powers would be to bring a local government into direct relation with the federal government based as already stated on the principle of autonomy and equity between the three tiers of government. Local government would thereby cease to be a creation and function of the state government making it as unconstitutional for the state to acts on matters reserved for the local government. Despite this demand however, constitutional reforms aimed at enabling the guarantee of local government autonomy have consistently yielded insignificant results. Thus both the earlier 1979 Constitution and the present 1999 Constitution of the Federal Republic of Nigeria, left local government as a residual matter and therefore under the legislative competence of the sub-national government, that is the state' governments. ${ }^{42}$

This constitutional position under S. 4(7) and 7(1) is in consonance with the tenet and spirit of federalism for the autonomy of the state government under a federal arrangement include its powers and control over local affairs, local government being one of such matters. Federalism therefore guarantees states or sub-national autonomy whereas local or sub-sub-national government should be under the control of the sub-national or state government. The agitation for the elevation of local government to the status of autonomous third tier government under the Nigerian federation to be funded and control directly by the federal government would imply the abolition of the distinction between matters of local concern and those of national concern in a federal system of government.

${ }^{42}$ S. 4 (7) and 5(2) 1999 CFRN. 
The basis for the division of powers under a federal polity being that within the framework of a central government charged with matters of general or national concern, those of local concern should be managed by the state or sub-national government. Federal government involvement in local government is therefore a contradiction of the principle of federalism.

\section{The Constitutional Limit to Local Government Autonomy in Nigeria}

It can be gleaned from the various constitutional provisions that it was not the intendment by the makers of the constitution to provide for an autonomous local government system in the sense of government free from control or interference from the other levels of government. For example section 88 of the Constitution confers on the National Assembly power by resolution published in the official gazette to carry out an investigation into any matter or thing with respect to which it has power to make laws; and the conduct of affairs of any person, authority, ministry or government department charged or intended to be charged with the duty of or responsibility for executing or administering laws enacted by the National Assembly and disbursing or administering moneys appropriated or to be appropriated by the National Assembly. A similar power is conferred on the House of Assembly of a state under section 128 of the Constitution. Thus both the National Assembly and the House of Assembly of a state of the federation may investigate affairs of the local government council, for instance in respect of the use of statutory allocation of revenue to it or to expose corruption, inefficiency, or waste in the management of local government. ${ }^{43}$

Further the responsibility of organizing, undertaking and supervising local government council's election within the state is vested in the states independent electoral commission. SIEC shall fix the date for the conduct of election and ensure the conduct of same according to schedule. ${ }^{44}$ Also the constitutional provision for joint account whereby fund meant for local government in a state are paid first into a joint account from where the state transmits funds meant for local government also deprives the local government council of their autonomy. ${ }^{45}$ Thus in Attorney General of Ogun State v. Attorney General of the Federation $^{46}$ the Supreme Court of Nigeria upheld the contention that the federal government has no power to pay the amount standing to the credit of the local government councils in the federation account directly to the councils. Such manner of payment according to the Supreme Court is illegal and unconstitutional.

It is further the duty of the state to apportion the local government shares among local government councils in the state under a law made by the State

\footnotetext{
${ }^{43}$ See section $88(2)$.

${ }^{44}$ A.G. Abia v. A.G federation (2002) 6 NWLR (Pt. 763)264 SC, (2006) 16 NWLR (Pt. 1005)265 SC.

${ }^{45}$ See section 162(5)(6)] Alex I. Ekwueme; "much Ado about New Local Governments: Constitutional Provision," the Guardian Saturday 2004.

${ }^{46}(2002) 18$ NWLR (Pt. 789) 232.

${ }^{47}$ A.G Ogun v. A.G Federation supra.
} 
House of Assembly of the state. ${ }^{47}$ The Supreme Court has however held that neither the federal government nor the states has constitutional power to withheld allocation meant for the constitutionally recognized local government councils. ${ }^{48}$ In Attorney General of Lagos State v. Attorney General of the Federa$\operatorname{tion}^{49}$ the Supreme Court of Nigeria stated "the right and title of a state government to the amount payable to it pursuant to section 162(5) of the Constitution is indisputable". The subsection confers the legal title to the amount in question on the states subject to a trust in favour of their local government councils.

\section{Strengthening the Local Government System within the Precepts of a Federal Structure}

The essence of this subheading is to discuss the areas of constitutional restructuring under the extant constitution with the aim of strengthening local government at the grass root. This entails a review of the constitutional lacuna, loopholes, and unfederal and contradictory provisions under the Constitution that required reviewable for the purpose of strengthening on the one hand the Nigerian federal practices and on the other hand local government system.

One of these provisions is the constitutional provision of the number of local government areas in the country and the enumeration of their names and their respective headquarters. ${ }^{50}$ This constitutional provision is a serious clog to the powers of the states over local government creation since it will require amendment before any new local government area may be lawfully created and unfortunately no state House of Assembly possesses the constitutional power to amend this constitutional provision. It therefore makes it difficult if not impossible for states to exercise their powers of creating or restructuring local government within the purview of the powers conferred on them under section 7(1) of the Constitution. It is therefore suggested that this provision of section 3(6) be expunged from the constitution.

Another area of confusion is the provision of section 7(6) (a) and 162(5) which provides for allocation of funds to the local government from the federation account. This provision is an aberration as local government is better left to be entirely the subject of the state. The system of allocation from federation account to local government is mischievously based on political consideration aimed at financially empowering the people from the region that have more number of local government councils thereby marginalizing those with less local government councils. It need be recalled that these existing local government councils were created by the successive federal military governments dominated by one region of the country. These governments created more number of local governments' councils in their region so as to attract larger amount of federal

\footnotetext{
${ }^{48}$ See Attorney General of Lagos state v. Attorney General of the Federation supra.

${ }^{49}$ Supra.

${ }^{50}$ Section 3(6) provides: there shall be seven hundred and sixty-eight local government areas in Nigeria as shown in the second column of part 1 of the first Schedule to this Constitution and six area councils as shown in part 11 of that Schedule.
} 
revenue to their region. In fact this section 7(6) (a) remained a clog in the wheel of progress for local government development in Nigeria as it is the primary basis for the inclusion of the provision in section 8(5) and (6) which involves the National Assembly in the process of creating a new local government by any state of the federation. Thus where the provision of section 7(6) (a) and 162(5) to be expunged from the Constitution, the provision of section 8(5) and (6) which involved the National Assembly in local government creation would become meaningless as the National Assembly of the federal government would have no business with the affairs of local government. The provision of section 8(5) and (6) have made it impossible for the states to carry out their functions under section 7(1) of the Constitution of ensuring that local governance becomes an effective tool for grass root mobilization as the various attempts by various states to create additional local government councils to bring governance to the grass root were aborted as the National Assembly failed to ratify such creation as required by section 8(5) and (6) of the Constitution.

In Attorney General Lagos state v. Attorney General Federation ${ }^{51}$ the Supreme Court of Nigeria held that by virtue of the section 7(1) and 8(3) of the 1999 Constitution, a state government is vested with the power to create new local government areas within its domain, but the power to so do is not absolute. It is subject to an act of the National Assembly amending section three and part 1 of the First Schedule to the Constitution and until such an Act is enacted by the National Assembly any new local government area purportedly created by any State Government is inchoate and not effectively constituted. None of such newly created new local government areas is entitled to receive any fund from the Federation Account until the creation is ratified by the National Assembly.

One would want to question the essence of this requirement for approval of National Assembly before a newly created local government councils becomes operative. ${ }^{52}$ Why must the state government which the constitution in section $7(1)$ and (2) of the 1999 Constitution gives the primary responsibility of sustaining local governments not be able to set in motion and complete the process of amendment to reflect those newly created local government areas? What is

\footnotetext{
${ }^{51}$ (2004) 18 FWLR (Pt. 904) I SC.

${ }^{52}$ In Ikwor-East Local Government v. Deputy Sheriff and Anor., Unreported Suit No. $\mathrm{HAB} / 12 \mathrm{M} / 2002 /$ the issue was the validity or otherwise of the local government creation exercise carried out by the government of Ebonyi state through the State House of Assembly which the National Assembly refused to validate. The trial judge held inter-alia; "if the exercise of power conferred on the state assembly by section 8(3) of the Constitution is meant to be self-executing then section $8(5)$ and (6) would become unnecessary and there would have been no need to peg the number of local government to $768 \ldots$ in the schedule to the constitution Ebonyi state consists of 13 local government areas. That number and ipso facto, the number in section 3(6) can only be altered by the National Assembly pursuant to section 8(5). Accordingly any local government area created by a state Assembly pursuant to section 8(3) of the Constitution cannot become a local government area within the meaning of the Constitution until the National Assembly exercises its powers under section $8(5)$ of the Constitution. It is a notorious fact, and I have no evidence to the contrary, that since the life of the National Assembly, it has not made an enactment pursuant to section 8(5) of the Constitution and ipso facto, the number of local governments in Nigeria in section 3(6) remains unchanged."
} 
the business of the National Assembly of the central government with the creation of a new local government area by a component state of the Federation within the state territorial boundary? It is submitted that this requirement would not have formed part of the Constitution if not because of the politics of revenue allocation by the federal government to the local government councils. Therefore where this provisions for revenue allocation to local government councils from the federation Account is to be abolished, the National Assembly would not be required to approve the creation of any new local government council by the states of the Federation. ${ }^{53}$ It is therefore suggested that no direct allocation of fund from the federation account be made to the local government councils. Instead a lump allocation should be made to the states governments on behalf of their local government areas and the state government is empowered to distribute this amount equally amongst the local government councils in the state.

Another area of constitutional aberration is the area of federal control or interference with local government affairs with regard to registration of voters. By virtue of section 153(1) (f) the Independent National Electoral Commission (INEC), an agency of the Federal Government has powers to arrange and conduct the registration of persons qualified to vote and prepare, maintain and revise the register of voters "for the purpose of any election under this Constitution". Similarly paragraph II, item E of the Concurrent Legislative List provides that "the National Assembly may make laws for the federation with respect to the registration of voters and the procedure regulating election to a local government council". On the other hand the actual conduct of election to the local government councils is reposed on the state's electoral body; S.I.E.C, an agency of the state government.

The implication of the above is that the State Electoral body, SIEC cannot really organize or hold election to local government councils in the absence of voters register prepared by INEC. These undermined the powers and responsibilities of the state government on local government under section 7(1) of the Constitution. In Akanor v. Lagos State Electoral Commission ${ }^{54}$ the Lagos state electoral commission purported to conduct election without an updated register of voters made by INEC in accordance with the similar provision under the 1979 Constitution. This action was nullified as unconstitutional and illegal by the court. $^{55}$

This constitutional requirement for register of voters by a federal electoral body is an aberration to the notion of federalism and a clog in the wheel of democratization of local government system. It is of course unnecessary and ought to be expunged. This is because register of voter is a matter of local concern and

\footnotetext{
${ }^{53}$ Many states for example, Kogi, Lagos, Niger, Oyo, Ebonyi etc. created more additional local government areas in line with their powers under the constitution. But the federal government refused to recognize them as the National Assembly did not ratify them. ${ }^{54}$ (1981) 1 NCLR 51.

${ }^{55}$ See also Lawal v. Lagos State Electoral Commission (1981) INLR 63, Ajayi v. Lagos State (1981) NCLR 94.
} 
such should be left to the states or local councils. It has no business being placed under the control of the Federal Government as it will stifle grass root democracy since the conduct of election to the local government by the state government is depended on the compiling of voters register. It is recommended that state independent electoral commission be allowed to carry out every functions related to the conduct of election including the revisions of voters register.

\section{Conclusion}

This work has expounded on the autonomy of local governments especially in a federal structure. A substantial level of autonomy at the local government levels is important for the promotion of grassroots democracy and self rule among the various diverse interests that make up the national polity. Local government avails the outvoted minority of the electorate the opportunity to participate in governance at the local level. It makes democracy meaningful to these local people if their immediate affairs are not dictated by the central functionaries but managed locally by themselves. Relationship between local government system and democracy lies on the premise that both functions promote the local economy, and social service for the realization of the social development of the local people through the empowerment of the local people in decision making.

The Nigerian federal constitution in order to promote local governance made provisions for the existence and sustenance of local government. The constitution however failed to make clear provisions as to the form of organization for local government, leaving it at the discretion of the states governments. The $\mathrm{Ni}$ gerian constitution also provided for a cumbersome procedure for creation of a new or additional local government area by a state government. It further made provisions whereby the federal government at the centre can interfere and frustrate the state's exercise of this constitutional function of local government creation. These and other un-federal and contradictory provisions have been critically reviewed. We have therefore recommended for the deletion of sections 3(6), 7(6) (a), 162(5), 8(5) and (6) and 153(1) (f) of the Constitution which give opportunity to the federal government to interfere with the States' power over the creation and management of the local government system. Expunging these constitutional provisions will place the local government system in their proper position under a truly federal structure. It is believed that these recommendations can strengthen the local government as an agent of grassroots development and participatory democracy.

\section{References}

A. O. OJO (1773). Political Science and Government of Nigeria. Ilesha: Ilesanmi Press Limited.

Adeyemo, D. O. (2005). Local Government in Nigeria; A Historical Perspective. Journal of Local Government Studies, 80. https://doi.org/10.1080/09718923.2005.11892462

Agboola, T. O. (2016). The Challenges of State/Local Government Creation in Nigeria Critical Analysis. International Journal of Politics and Good Governance, 7, 1-18. 
Appadorai, A. (1975). The Substance of Politics. New Delhi: Oxford University Press.

Asaju, K. (2010). Local Government Autonomy in Nigeria: Politics and Challenges of the 1999 Constitution. International Journal of Advanced Legal Studies and Governance, 1, 98-113.

Bhagwan, V., \& Bhushan, V. (2009) World Constitutions, A Comparative Study (9th Revised \& Enlarged Edition). New Delhi: Sterling Publishers Limited.

Congress of Local and Regional Authorities (2017). https://rm.coe.int/local-and-regional-democracy-in-switzerland/1680750d61

Dalhatu, S. (2006). Essays on Local Government Administration: Fostering Better Service Delivery, Record Keeping, Accountability and Empowerment at the Local Government. Kano: Benchmark Publishers.

Davey, K. J. (1995). Local Autonomy and Independent Revenue. Journal of Public Administration, 49, 45. https://doi.org/10.1111/j.1467-9299.1971.tb00045.x

Ekukpo, C. P. (1994). Local Government Administration in Modern Nigeria. Ikot Ekpene: Egme Publication.

Ekwueme, A. I. (2004). Much Ado about New Local Governments: Constitutional Provision. The Guardian Saturday.

European Charter of Local Government Council of Europe Treaties E.T.S No 122.

Federal Republic of Nigeria (1979). Guidelines for Local Government Reforms. Kaduna: Government Printers.

Gamkhers, S., \& Pickerill, M. (2012). The State of American Federalism 2011-2012: A Fend for Yourself and Activist Form of Bottom-Up Federalism. The Journey of Federalism, 42, 357.

Gboyega, A. (2001). Local Autonomy in Federal Politics: The Nigerian Local Government System in Historical Perspective. Being a Paper Presented at an International Conference on New Directions Federalism in African, Abuja Nigeria.

Hatchard, J., Ndulo, M., \& Slinn, P. (2004). Comparative Constitutionalism and Good Governance in the Commonwealth. Cambridge: Cambridge University Press. https://doi.org/10.1017/CBO9780511494314

Igbuzor, O. (2003). Local Government Reform and Constitutional Review in Nigeria. Lagos: Centre for Democracy and Development (CDD).

Kimura, Limit of Good Governance in Decentralization and Local Autonomy-Ideal and Reality of Local Governance.

Nwabueze, B. O. (1983). Federalism in Nigeria under the Presidential Constitution. London: Sweet and Maxwell.

Nwabueze, B. O. (2003). Constitutional Democracy in Africa Vol. 1. Ibadan: Spectrum Books Ltd.

Nwabuze, B. O. (1993). Ideas and Facts in Constitution Making (p. 244). The Morohundiya Lectures.

Nwankwo, B. C. (1992). Authority in Government, Nigeria and World Politics in Focus. Enugu: Almond Publishers.

Odenigwe, G. A. (1977). A New System of Local Government. Enugu: Nwamife Publishers.

Oluyede, P. A. O. (1992). Constitutional Law in Nigeria. Ibadan: Evans Brothers Nigeria Publishers Ltd.

Omale, I. (2005). New Perspectives in Public Sector Management in Nigeria. Ankpa: Ultimate Publishers. 
Orewa, G. O., \& Adewumi, J. B. (1992). Local Government in Nigeria: The Changing Scene: Vol. II. Benin: Ethiope Publishing Corporation.

Publius: The Journal of Federalism. USA Oxford University Press.

Sasaki, N. (1984). Atarashii Chiho Seihu [The New Local Government.]. Ashi Shobo.

Squire, P. et al. (1997). Dynamics of Democracy (2nd ed.). Chicago: Brown and Benchmark.

Ugwu, S. C. (2001). Issues in Local Government and Urban Administration in Nigeria. Enugu: Academic Publishing Company. 